\title{
Serpin B4
}

National Cancer Institute

\section{Source}

National Cancer Institute. Serpin B4. NCI Thesaurus. Code C148326.

Serpin B4 (390 aa, $45 \mathrm{kDa}$ ) is encoded by the human SERPINB4 gene. This protein plays a role in the inhibition of protease activity for enzymes such as granzyme $\mathrm{M}$. 